\title{
Corrigendum to Implications of Strategic Alliances for Earnings Quality and Capital Market Investors [Journal of Business Research, volume 69, Issue 9, September 2014, Pages 1806-1816]
}

\author{
Sebahattin Demirkan*, Irem Demirkan ${ }^{1}$ \\ Faculty of Business Administration, Bilkent University, Bilkent, Ankara 06800, Turkey
}

The authors regret that William M. Cready has not been added as a co-author to this article when it was published originally in year 2014 . Dr. Cready gave important support when Dr. Seb Demirkan was initially developing and introducing this new area in accounting. Dr. Cready really deserves to be part of this innovative and impactful interdisciplinary research in accounting. Authors continue to work in this area, and get inspiration from him time to time. The authors would like to apologize for any inconvenience caused by this omission. The order of the authors according to their contribution to this publication is following; Sebahattin Demirkan* (University of Maryland), Irem Demirkan (Loyola University), William M. Cready (University of Texas at Dallas)

The authors would like to apologise for any inconvenience caused.

DOI of original article: http://dx.doi.org/10.1016/j.jbusres.2013.12.009

* Corresponding author. Tel.: +90 3122902926.

1 Tel.: +903122902415.

E-mail addresses: iremdemirkan@bilkent.edu.tr (S. Demirkan), sdemirkan@gmail.com (I. Demirkan). 